\title{
STASIS AND CHANGE: \\ RUSSIA AND THE EMERGENCE OF AN ANTI-HEGEMONIC WORLD ORDER
}

\author{
Richard SAKWA
}

\begin{abstract}
This chapter argues that after a quarter century of stasis, the pattern of world order is changing and the inter-cold war period of the cold peace is giving way not to a thaw, but to the reentrenchment of bipolar confrontation between the expansive liberal international order and the resistance of a group of states including Russia. Like the First Cold War, the second is also about the conflicting views of world order as the U.S.-led liberal international order is challenged by the emergence of a putative anti-hegemonic alignment between Russia, China and their allies in the emerging alternative architecture of world affairs - especially the Shanghai Cooperation Organization (SCO) and BRICS (Brazil, Russia, India, China, South Africa). The clash between Russia and the West, in this sense, is only an early version - and ultimately perhaps not the most significant - of the challenges against the long-term stasis in international affairs. Although the sinews of a post-Western world are emerging, it remains to be seen whether bodies like SCO and BRICS will be able to sustain the multilateralism of the last seven decades in the absence of the hegemon that had provided the security and support for such multilaterialism to thrive.
\end{abstract}

\section{Introduction}

After a quarter century of stasis, the pattern of world order is changing. The inter-cold war period of the cold peace is giving way not to a thaw, but to the re-entrenchment of bipolar confrontation. Like the First Cold War, the second is also about the conflicting views of world order, although the language and modalities differ. The U.S.-led liberal international order is challenged by the emergence of a putative anti-hegemonic alignment (Sakwa 2017). This phenomenon is much bigger than simply the re-emergence of China as a global actor or Russia's neo-revisionist stance that challenges the practices of the previously hegemonic world order. Both countries defend the multilateral norms of the international system, but challenge the assumption that the liberal world order is synonymous with order itself. The two countries and to varying degrees their allies in the emerging alternative architecture of world affairs notably the Shanghai Cooperation Organisation (SCO) and the BRICS (Brazil, Russia, India, China, South Africa) - have also adopted elements of the neo-revisionist position, and this provides the ideational framework for the emerging anti-hegemonic world order.

Members of this nascent alignment stress that it is not directed against anyone. The stated goal is to restore balance in world affairs within the framework not simply of multipolarity (although polycentrism, as Russians put it, is a key value), but through a positive agenda of a new model of international relations. The alignment is thus not "counter" hegemonic, which would simply replicate the existing pattern of international behaviour, but "anti" hegemonic, questioning the very idea that a single state and its allies can claim "primacy" in world affairs or that their ideology can be considered universal. This position was already implicitly asserted in 1945 in the Yalta system of great power relationships, but was then "democratised" through the principles enunciated in the Helsinki Final Act of August 1975. In the First Cold War, the U.S.led liberal international order was challenged by the Soviet bloc within the framework of a bipolar international order, but in the post-1989 period, the assertion of unipolarity undermined the principles of both Yalta and Helsinki (Ikenberry 2011). Today the aspirations for multipolarity are embedded in the broader emergence of two contesting visions of world order (Smith 2013). The confrontation between the expansive liberal international order and the 
resistance of a group of states provoked the Second Cold War. The Trump phenomenon then emerged as an intervening variable, challenging both post-war representations of American hegemony and those who were coalescing in resistance to it.

This chapter seeks to explore Russia's perceptions regarding the emergence of an antihegemonic world order at a time when the stasis in the international system is being replaced by dynamics of change. The first section discusses the end of stasis in the international system and how Russia responds to it - particularly in terms of its relations with the West. The second section elaborates on the factors shaping Russia's distinct neo-revisionism which has emerged largely as a reaction to the absence of transformation of the European security system at the end of the Cold War. The third section focuses on the dynamics of change in the international system and the way Russia tries to redefine its relations with the West as well as other rising powers like China.

\section{The International System and the End of Stasis}

The emergence of a putative alternative model of world order promises to disrupt the long stasis in international affairs that predominated since 1945. Although 1989 brought important changes to the practice of international politics, the international system was not fundamentally transformed (Pouliot 2010). Equally, the current period of dynamic change is not intended by the key subaltern actors to revise the international system but only its practices. This is why Russia and China are not revisionist powers, but neo-revisionist: seeking to change how the existing works rather than changing the system itself. In the quarter century of the inter-Cold War years (1989-2014), otherwise known as the period of the cold peace, the liberal international order became more ambitious (within the framework of the ideology of globalisation and the "end of history"), but the post-1945 order prevailed. The main process after 1989 was the "enlargement" of the liberal order accompanied by extensive claims to hegemony. From that perspective, 1989 did not represent such a radical break, other than for the countries directly involved. Only after the expanding liberal order "hit reality" has some rethinking begun (Mearsheimer 2018).

Only now, some 70 years after the end of the Second World War, is a major shift taking place in the international system. Acharya (2017) describes the new system as "multiplex", while Flockhart (2016) describes the phenomenon as a "multi-order" world. The central point is not only that unipolarity has given way to multipolarity, but that the framework for relations between orders marks a qualitative change in international relations, and thus represents a return to the "transformative" agenda outlined by Mikhail Gorbachev at the end of the First Cold War. The inter-Cold War period was characterised by tension between enlargement and transformation, but with the onset of the Second Cold War in 2014, the long period of stasis when the U.S.-led liberal order predominated (although challenged by the Soviet Union and its allies for some of the period) is now giving way to a renewed period of confrontation. While Gorbachev and his successors at the head of the Russian state sought a positive transformation within the framework of the post-Second War international system, the Second Cold War is characterised by a negative transformation in which the logic of confrontation has been restored.

Stasis means more than simply stagnation, but it does suggest a certain inflexibility, immobility and absence of institutional or ideational innovation. It is in the latter sense that the term is used to describe the post-First Cold War security order in Europe. The foundations of that order were laid after 1945 in conditions of a developing bipolar confrontation between the Soviet bloc on the one hand and the U.S. and its allies on the other. This Atlantic system became the core of the global U.S.-led liberal international order. After 1989, this order - dubbed by Russian scholars the "Historical West" - began a process of enlargement to Eastern Europe, while at the 
same time under the guise of "globalisation" it made claims to be universal. However, from the very beginning, Gorbachev, the Soviet leader who did the main work in bringing the Cold War to an end, believed that instead of enlargement being the governing process, the conduct of international relations should have been transformed to take advantage of the uniquely benign situation of the late 1980 and early 1990s. The idea was that the Soviet Union, and later Russia under its leader Boris Yeltsin, would engage with the Historical West as the co-founders of a new political community, what could putatively be called a "Greater West". The deeper aspiration no doubt was to strip out the elements of American globalism (the power system) from globalisation (the convergence of world politics through economic and societal interactions).

This would have required some institutional innovation and ideational creativity, but the project for a positive transcendence of the logic of conflict, Russian political leaders and academics continue to insist, was not only feasible but essential if the Cold War and confrontation were not to return to divide the continent. However, old-style globalism remained and in certain respects was reinforced. Russia refused to accept the role of junior partner in an already established enterprise, but sought to join that enterprise as an equal, believing thereby that the enterprise would be transformed by its membership. In other words, Russia's assertion of its great power status did not entail the reassertion of some sort of imperial project, particularly in its neighbourhood, but sought to be institutionalised through the transformation of the traditional Atlantic community into a pan-European and indeed global community. This would have avoided the tension generated by the merger between democratisation and geopolitics that structured the cold peace and then generated the Second Cold War. The "democratic peace theory" in this period assumed that the enlargement of the sphere of liberal democracy would guarantee the security of the Atlantic system. It was thus assumed that joining NATO was the "democratic" thing to do, even if large sections of the relevant populations were opposed to the idea.

Russia's ideas for an alternative were only slowly formulated, and to this day lack substantive theoretical articulation. This is why Russia is sometimes seen as a "spoiler": unwilling to accept what is posed as universal values, yet unable to formulate an intellectually and attractive alternative. Instead, the enlargement agenda, specifically in Europe but globally as well in the form of the agenda of the liberal international order became hegemonic. However, the contradictions in that order, above all the tension between its norms and power system in which it was embedded - the tension between democratisation and geopolitics (condemned by Russia as "double standards") - in the end provoked a reaction which gave rise to an anti-hegemonic alignment.

This is not an alliance let alone a bloc, but the alignment is gradually developing a more ramified institutional architecture, while at the same time, formulating a more coherent model of an alternative world order - all within the framework of the existing international system. The clash of orders is accompanied by contending models of international affairs. On the one side, realists assert that structural factors shape international politics, although there is no consensus about what the relevant structures are. Offensive realists stress the importance of anarchy as the primary condition, with international relations determined by the struggle for power and predominance by an international system populated by "billiard ball" states, in which domestic regimes and systems of governance are irrelevant (Mearsheimer 2014a). At the other extreme are constructivists, who argue that identities are shaped by mutual interaction between the "self" and "other" (Wendt 1992). Equally, realists are countered by the partisans of the "liberal world order" who assert that the rules-based system that has become predominant since 1945, and reinforced by Western "victory" over the Soviet Union after the end of the First Cold 
War in 1989, means that the traditional lexicon of great power politics, along with spheres of influence, balancing and bloc politics, have become anachronistic.

In this conception, the democratic sphere is universal and assumes a monistic ideological and institutional character, whereas Gorbachev's early proposal for a common European home, taken up by his successors in the form of the idea of "greater Europe", assumes a pluralism of ideational and institutional forms. In other words, expansive globalism (although embedded in the putative universalism of globalisation) ran into the rocks of Sino-Russian particularism although this particularism is embedded in a conservative form of internationalism.

This only makes sense in the context of a credible understanding of the international system. Drawing on English School thinkers, I argue that the international system today is a fundamental hybrid, in which realist concerns about state sovereignty, security and autonomy predominate at the horizontal level in relations between states; but at the vertical level neorevisionist states such as Russia and China are committed to the institutions of multilateral governance (Sakwa 2017). Thus the international system has a binary structure. At the top there is the UN and the ramified "secondary institutions" (as termed by English School theorists) of international legal, economic, environmental and financial regulation. Although the autonomous power of these institutions should not be exaggerated, neither should they be dismissed. The UN remains the main source of legitimacy for international cooperative endeavours. At the lower level we have an increasing number of independent states, but their interactions have also evolved.

The triumphant U.S. after the Second World War embedded its hegemony in the Atlantic alliance system, and on the global level advanced the multilateral and universal practices of the liberal world order. After the First Cold War, this multidimensional alliance system became the core of an enlarging "world order" with universalistic aspirations. One of the distinctive features of the Second Cold War is that the U.S. under President Donald J. Trump has emerged as a genuinely revisionist power, no longer ready to be constrained either by the liberal international order of which it was once the core, or by the structures of multilateral governance that it had done so much to foster in the years after 1945. At a time when the traditional liberal world order is beginning to unravel (although the extent of this should not be exaggerated), the alternative "anti-hegemonic" (or post-Western) world order is beginning to take shape, intended not to challenge the norms of the international system as they have developed since the Second World War, and codified in the institutions of global governance, but to question the hegemonic role of the states comprising the liberal world order. The challenge is to the practices of international affairs as conducted by the U.S. and its allies, and not the norms on which the international system today is governed. This is why Russia, China and their allies are neo-revisionist, and not out-and-out revisionist.

For various reasons Russia was not incorporated into the "Historical West", despite its earlier aspirations to join, and for more obvious reasons neither ultimately was China, although both took advantage of what the liberal world order had to offer. For status and a variety of historical and security reasons, neither could join the U.S.-led liberal international order as subaltern powers. Their fundamental argument is that the liberal world order is not synonymous with order itself. Washington and its allies represent one power system, and although this system has done much to advance the public goods associated with rules-based multilateral development, it also remains a particularistic system, despite its pretensions to universality. The "secondary institutions" of international society have now come to represent an autonomous level of universal order, based on principles and ideas that are far from the proprietary invention of the U.S.-led liberal international order (Dunne \& Reut-Smith 2017). The ideas and principles underlying this universal order have long been debated in most civilisations, and although their normative formulation was greatly advanced after the Second World War, notably in the UN's 
Universal Declaration of Human Rights of December 1948, even this Declaration was formulated with the participation of all the major powers of the time.

In this context, the fundamental cleavage in international politics today is between the partisans of the enlargement of the liberal international order (even if the baton of leadership may be passing from the U.S. to European states), and those who defend an anti-hegemonic view. The process of enlargement inevitability has an imperial element, if not conducted in a classically imperial manner (this is the fundamental source of "double standards" in international affairs). And imperial aggrandisement inevitably provokes a reaction. Russia, China and other powers are beginning to shape the lineaments of an alternative world order, based not on "antiWesternism" let alone opposition to "globalisation", but for the defence of pluralism in the international system. Thus an anti-hegemonic alignment is gradually taking shape, with such institutions as the SCO, BRICS and other informal ties at its core. This is post-Western rather than anti-Western (Stuenkel 2016). It betokens the onset of Flockhart's "multi-order" world and the multiplex arrangements described by Acharya. The nascent anti-hegemonic alignment defends not so much globalisation as the deepening integration of global markets and development strategies through intensified internationalism, in which states retain the power to shape their industrial strategies and social policies, and to resist the supra-nationalism of investor-state adjudication mechanisms. Because of the continued vertical commitment to multilateral institutions of global governance, this is more than a reversion to traditional Westphalian internationalism. Classic definitions of globalisation were understood to represent an ideological project for the enlargement of a specific model of economic relations, with U.S. power at its core (Panarin 1998), whereas the anti-hegemonism of the rising powers insists on a modified model of multilateral globalism.

\section{Russia and Neo-revisionism}

How does Russia fit into all of this? At the end of the Cold War Russia advanced a programme to transform the European security system, and by implication, the pattern of global politics entrenched in Cold War institutions and ideologies. Gorbachev talked of a "common European home", which fitted into the classic Gaullist discourse of "Europe from the Atlantic to the Urals" and François Mitterrand's idea of a "confederation of Europe". Moscow insisted that it was the instigator of the end of the Cold War, and had thus won the right to be the co-author of a transformed post-Cold War world. With Russia's inclusion, the "Historical West" would become a "Greater West", and the structures of the Cold War would be dismantled as a common developmental programme was devised. Fearing normative dilution, institutional incoherence and, perhaps above all, the weakening of American leadership (globalism), this programme of radical transformation was rejected in favour of an enlargement agenda of the existing structures, those that had apparently achieved "victory" over the Soviet Union.

Wohlforth and Zubok $(2017,416)$ argue that "There were no easy 'missed opportunities' to integrate the USSR or post-Soviet Russia seamlessly into the West. To have achieved that outcome would have taken statesmanship of the sort rarely if ever witnessed in international politics." Equally, there was not much, in their view, that Russia could have done to avoid the effects of disintegration and the collapse of the Soviet bloc. There was, they rightly argue, no "vast conspiracy" to keep the country down, and instead "Russia is not an abiding preoccupation but rather an inconvenience for the West, which has strong reasons not to put its core approach to security at risk to accommodate Moscow." This is true as far as it goes, but neglects the quite practical ideas put forward by the Soviet leadership at the time that provided a route out of Europe's endemic conflicts. In other words, their argument makes sense as seen from Washington, but not from the continental European capitals. The failure to seize the opportunity to build a pan-European peace order gave rise to the 25 years of the cold peace, 
provoking in the end the Second Cold War. In other words, no exceptional statesmanship was required, but just openness to exploit an opportunity to bring Russia and its neighbours into an inclusive and indivisible security system, thus precluding the onset of an intensifying security dilemma that provoked the 2008 Georgian war and the 2014 Ukraine conflict. While the Congress of Vienna quickly found a way to incorporate defeated France into the post-war order, the Treaty of Versailles failed to do so for Germany and thus contributed to creating the conditions for the Second World War (Kissinger 2014). The post-1991 settlement has elements of the second approach, although couched in the language of friendship and support, and thus after a "25 years' crisis" (Sakwa 2008) the First Cold War gave way to the Second.

Given that the Soviet system had dissolved and the country disintegrated, the victory discourse seemed plausible. However, politics of transformation is something that Russia would not give up so easily, along with those aligned with it outside of the liberal world order, and even within. As the radicalism of Bernie Sanders and Jeremy Corbyn suggests, the programme of transformation has deep roots in the heartlands of the liberal international order, accompanied by resurgent peace and non-aligned movements worried by the renewed drift towards militarism and confrontation. New political thinking is not a purely Russian phenomenon. The transformation agenda in international politics is accompanied by the desire for change domestically. The two are connected, and the frozen character in international relations intensified certain governing practices that introduced policy stasis into domestic politics, which in the end exploded in a wave of populist nationalism. It is hardly surprising that the right and left "populism" of today is provoked by hostility to what are perceived as global elites concerned only with the mobility of capital, labour, goods and services, while neglecting the concerns of domestic populations, who increasingly perceive themselves as the victims of globalisation. Post-First Cold War elites failed in addition to create a viable European security order, provoking the Second Cold War.

While 1989 may well have been a "masterpiece of history" (Savranskaya, Blanton \& Zubok 2010), the absence of institutional and ideational innovation at the end of the Cold War is striking. Everything in Russia's history militated against it becoming simply a subordinate element of an expanding "Historical West". At first, Russia sought to devise a fundamental partnership with the enlarging EU, but even that faltered by the mid-2000s, as a wave of traditionally anti-Russian post-communist countries joined (Maas 2016; Forsberg \& Haukkala 2016). Even more disruptive was NATO enlargement, something that realists, such as George Kennan, warned would ultimately provoke a Russian counter-reaction. Equally portentous was the way that the enlargement agenda incorporated the structures of the Cold War into the expanding system. Although there was no deliberate attempt to exclude Russia, institutions such as the NATO-Russia Council were clearly devised within the framework of mitigation rather than transformational strategies. The structural condition of the cold peace was the merger of democratisation and geopolitical agendas in the expanding West, in which normative concerns fused with the enlargement of the Atlantic security system. The result was "trans-democracy", based theoretically on liberal peace theory, but with enormous practical consequences (Sakwa 2017, 98-104).

As far as Russia was concerned, the 25 years of the cold peace failed to resolve any of the fundamental problems of European and global security. For Russia, NATO enlargement represented not only a betrayal of the verbal assurances apparently given at the time of German unification that the alliance would not move "one inch to the East" of the former East German territory (Savranskaya \& Blanton 2017), but represented a provocation that only intensified the security dilemma that the alliance was intended to avert. At the end of the Cold War, Russia was offered associate membership of an existing enterprise, the "Historic West", but Russia's enduring aspiration was to become a founder member of a transformed "Greater 
West". Membership of the transformed community would have provided a benign framework for Russia's domestic transformation, while removing the institutional and ideational structures of the Cold War. By contrast, joining an untransformed "Historic West" entailed status demotion, since it would have been a subaltern element in a U.S.-dominated system (Larson \& Shevchenko 2003). Even under Yeltsin in the 1990s this was hard to swallow, and under Putin in the 2000s there were attempts to find a new balance between Russian adaptation and foreign policy and developmental autonomy. By the time Putin returned to presidency in 2012 for his third term, Russia had shifted to a policy of neo-revisionism: maintaining a commitment to the norms of international society, but resisting the practices of U.S. primacy and globalism.

Neo-revisionism is the product of frustration that none of the three earlier phases of postcommunist Russian foreign policy had delivered the anticipated benefits. In the first phase, that of liberal internationalism accompanied by a nascent Atlanticism to temper Russia's traditional Eurocentric continentalism, all sides believed that a new international community could be established. It soon became clear that the West and Russia had very different ideas of how this could be achieved, with Russia still insisting on elements of transformation and co-constitution, and the West beginning the process of enlargement that would see NATO and the EU expand to Russia's borders. This helped provoke the second stage, the era of competitive coexistence, from the mid-1990s under the leadership of Yevgeny Primakov, first as foreign minister from January 1996 to September 1998, and thereafter as prime minister to May 1999. Policy shifted away from what was condemned as uncritical Atlanticism towards multipolarity, strategic competition with the West, and the emphasis on what at the time was called the RIC (Russia, India, China) combination. This did not preclude cooperation, but the nascent post-communist ideology of anti-hegemonism was now clearly articulated at the highest levels of Russian policy-making.

On coming to power in 2000, Putin inaugurated the third phase - the policy of new realism which tried to find a new framework for relations with the expanding West. It was realist to the degree that Putin defended elements of traditional Westphalian sovereignty, but it was new because it remained committed to the fundamental precepts of Gorbachev's "New Political Thinking" of the perestroika years, and sought to find new ways of overcoming the contradictions of the cold peace. Contrary to the standard image of Putin, he tried to find a "third way" in which Russia could integrate into the liberal international order while maintaining its strategic autonomy. In the end, no such formula could be found, precipitating the slide into neo-revisionism, which became the dominant paradigm of Russian foreign policy on Putin's return to the presidency in 2012. Putin was thoroughly disillusioned and disappointed in the West, especially after the intervention in Libya in 2011, and now sought to accelerate integrative endeavours in the post-Soviet space accompanied by the development of deeper ties with China. All this preceded the Ukraine crisis while at the same time helping shape Russia's response to that crisis following the overthrow of Viktor Yanukovych in February 2014. In other words, well before the onset of the Second Cold War in 2014, Putin had come to the conclusion that it was impossible to deal with the "Historical West", and accelerated moves towards Eurasian integration, the "pivot to the East", and insulating the Russian economy from dependence on the West.

Russia's neo-revisionism is a response to the dilemmas provoked by the absence of transformation of the European security system at the end of the Cold War. Wohlforth and Zubok (2017) rightly stress the impediments to such a transformation, but fail to take into account the specifically European context of the transformation. In global terms their realist paradigm is convincing, but the dynamics in Europe were potentially different. It is here that the normative impetus for transformation was highest, including domestic constituencies, as 
well as the institutional framework for a specific European international society, instantiated not only in the EU but also in the Council of Europe $(\mathrm{CoE})$ and Organisation for Security and Cooperation in Europe (OSCE). There were powerful countervailing trends, notably the U.S.dominated security system that was extrinsic to the transformative processes on the continent. The potential was there. After all, the EU would not exist were it not for the desire for a new type of peace order after the devastation of the Second World War. It did indeed take some visionary leadership to make it a reality, but mostly it emerged out of a recognition of mutual necessity (Milward 2000). However, the EU from the beginning was part of an Atlantic system, and after the Cold War it became the spearhead for the enlargement of that system (Mearsheimer 2014b).

On the other side, Russia since the end of the Cold War has been engaged in what Suzuki calls the "recognition game", the attempt by "frustrated great powers" to convince their peers that they are worthy members of the international system. It is important, as Suzuki argues, to understand the intentions of these putative great powers. Rather than subverting the norms of international society, Russia has in fact, along with China, been strengthening the normative structures of international society as they seek to gain legitimation for their desired status (Suzuki 2008). Thus, Russia has repeatedly called for the UN to remain the only legitimate arbiter for international interventions, and China has stepped in to defend the rules-based globalised economic order against Trumpian protectionism. However, because of the structure of hegemonic power in the international system, expressed above all in America's intention to maintain primacy, there is no path towards acceptance as a legitimate peer. This is why both Russia and China have moved towards the stance of neo-revisionism in which they no longer believe that it is in the gift of the hegemonic power to grant or withhold their respective status as great powers.

The realist paradigm considers Russia as no more and no less than a normal power, pursuing a rational (although that does not mean uncontested) foreign policy to maintain its position in the world and its neighbourhood. In that context, Moscow welcomed the conciliatory comments from Trump that it made sense to "get along" with Russia, and to that degree Moscow saw Trump's election in November 2016 as an opportunity genuinely to "reset" the relationship based on mutual respect for the interests of the other. Although Trump was committed to the maintenance of U.S. primacy (as evidenced in the sharp rise in defence spending), this would be achieved less through the multilateralism of the Obama-style "leadership" agenda, and instead a more muscular nationalism would be expressed through the assertion of "greatness" and transactional relations between the great powers. Geopolitics would be decoupled from democratisation. In other words, the plan was to normalise U.S. globalism and to decouple it from messianic ambitions to reshape the world in America's image. This suited Russia just fine. It meant the end of the "enlargement" agenda, in which democratisation was mixed with geopolitical concerns. Democracy promotion was curtailed and regime change was declared no longer on the agenda, much to the chagrin of those who considered Russia an "autocracy" (Carothers \& Brown 2018). However, it offered little in the way of system transformation of the sort desired by Russia, and to that degree Trump for Moscow represented little more than the opportunity for a more transactional relationship.

In the event, "Russiagate" served to constrain Trump's freedom of manoeuvre, and a more traditional U.S. foreign policy was reasserted. Even modest moves towards a more pragmatic relationship were stymied, although there was some cooperation on the ground in Syria and other global issues. The big picture was one of a continued impasse in Russia's relations with the West. Angela Merkel's re-election in Germany in September 2017 meant that the fragile status quo looked to be maintained in Europe, with the constant danger of a sharp deterioration. The post-Cold War attempt to maintain the Atlantic system and blunt the 
emergence of a more pluralistic international system looked set to continue, and with it the neo-containment policy. The U.S. sanctions are unlikely to be rescinded any time soon, and with Merkel's election the EU-sponsored ones look set to endure. However, history suggests that stasis in the international system generates disorder. The new inter-order balance between the U.S.-led liberal international order (although threatened from within by a potential U.S. defection) and the nascent anti-hegemonic alignment became constitutive of international relations. The Second Cold War may well endure as long as the first. Thus, the scene is set for prolonged confrontation and conflict, mitigated only by the UN and other secondary institutions of international society.

\section{The Dynamics of Change}

The West sees in Russia a heuristic image of itself, when in fact Russia has broken out of the traditional hermeneutics of European international relations. The starkest manifestation of this is the intensification of the continuing "pivot to the East", and in particular the close alignment with China accompanied by the strengthening of a "post-Western" world order encompassing such bodies as the SCO and BRICS, the heart of what is emerging as an anti-hegemonic alignment. Even Europe is shaken by the new dynamic of change, undermining the stasis in its affairs. The Atlantic enlargement strategy did not represent the resolution of the European security dilemma but the intensification of that problem. Relations between Russia and Europe, and with the West more generally, entered a deep impasse. The resolution of the problem it appeared could not be found from within the hermeneutics of the system itself, in which the liberal international order is faced by a number of rising powers loosely aligned in an antihegemonic bloc. There is a clash of orders, but at the same time some profound changes are taking place in international relations. In the framework of my two-level model of the international system, there are changes in the vertical axis - relations between states and orders and the institutions of global governance, above all the UN; and at the horizontal level, where the universalistic ambitions of the liberal international order are challenged by the emergence of the anti-hegemonic alignment as well as by non-systemic forces that seek to destroy the entirety of the international system to create, in particular, a new militant form of the Islamic ummah.

The clash between Russia and the West is only an early version, and ultimately perhaps not the most significant, of the challenges now challenging the long-term stasis in international affairs. International relations are now being reshaped, above all by the putative defection of the U.S. from the core of the liberal international order that it has so assiduously developed over the last 70 years. Many of the themes sounded by Trump were advanced in one form or another by American leaders before him, but none with such intensity or generated by ideas that are so fundamentally at odds with the multilateral normative Atlanticism that took shape after 1945. Trump is the consummate national realist, having little respect for international institutions or multilateral processes. By contrast, Russia's continuing commitment to international society as expressed in the UN and other "secondary institutions" means that Putin is a "conservative institutionalist", defending international law and the traditional rules of global governance (the intervention in Ukraine in 2014 was a revisionist act, but not part of a revisionist strategy). By contrast, after 1989 "democratic institutionalists" sought to use international society to "remedy drawbacks of traditional international law and develop new institutions by using the rule of the majority in roughly the same way it works in domestic politics" (Sokov 2018). There has long been a national realist strain in U.S. foreign policy, and it was this tendency which defeated Woodrow Wilson's attempts to create a multilateral world order in the wake of the First World War, and which kept the U.S. out of the League of Nations. Although Putin's policy is pragmatic and broadly realist, it is not realist in the strict definition of the term because of its willingness to share sovereignty with international institutions (notably the $\mathrm{UN}, \mathrm{CoE}$ and WTO), irrespective of its chequered relations with these bodies. 
At the same time, Russia challenges the attempt by democracy promotion activists and others to extend the scope of global governance bodies to disrupt the balance between sharing and maintaining sovereignty. The Responsibility to Protect (R2P) mechanism adopted in 2005 alarmed Russia and other states who considered it as an unwonted increase in the power of an international community dominated by the hegemonic powers, although in practice Russia engaged with R2P, despite the conservatism of its institutionalism (Averre \& Davies 2015). In the inter-Cold War years the main tension between Russia and the U.S. was between the two forms of institutionalism, although both camps evolved under different leaders. Even though Putin pursued a "new realist" policy, this represented an attempt to find some mode of integration and reconciliation with the democratic institutionalist agenda, but in the end this was doomed to fail. Nevertheless, even as neo-revisionism came to predominate in Russian foreign policy, this did not make Putin a realist of the old school. It is for this reason "any cooperation between them [Putin and Trump] can only be temporary and tactical." For Trump power is the key asset, deployed as finite asset, in a context where the balance of power is perceived to be moving away from the U.S. (Sokov 2018). Hence Trump insists that allies contribute more to their own defence, a long-term stance of U.S. leaders but now couched in terms of a transactional relationship rather than the traditional common commitment to multilateral institutions. It is in this light that Trump while campaigning in 2016 argued that NATO was "obsolete", and in power he made little effort to hide his distaste for the EU. He appeared to make NATO's Article 5 security guarantee dependent on whether a state met the $2 \%$ defence spending target set in Wales in September 2014. This represents a shift from collective to transactional defence, where security guarantees apply only if the appropriate contribution has been made.

Trump's approach to Russia is in line with his national realist view of international relations. He consistently stressed the importance of good relations with Russia (provoking the fears of the defenders of the traditional order in Washington), and pushed for the Helsinki summit with Putin in July 2018. However, this did not prevent him from taking numerous measures against Russia, including the sale of lethal arms to Ukraine, ramping up funding for the European Reassurance Initiative and reinforcing the U.S. troop presence in Europe, condemning the building of Nord Stream 2 as making Germany subservient to Russia, imposing harsh sanctions, expelling Russian diplomats and closing down Russian diplomatic facilities in the U.S. His overall strategy was in the Henry Kissinger mode (and he appears to have been advised by Kissinger), namely to try to recruit Russia to align with the U.S. against what was perceived as the greatest long-term threat, China. In practice, the sum of U.S. actions only reinforced the Russo-Chinese alignment, and there was zero chance of Russia defecting. At the best of times, the two countries saw the U.S. as an unreliable protagonist, and although there are plenty of voices in Moscow warning of the dangers of a too-close embrace with China, their alignment is far more than one built on the truly extraordinary relationship between Putin and Xi Jinping. The two share not only a strong personal relationship, but also the conservative institutionalist position. Thus Russia condemned Trump's withdrawal from the Joint Comprehensive Plan of Action (JCPOA, Iran nuclear deal) in May 2018 while emphasising the crucial role of the UN, while China emerged as the great defender of open markets and global economic governance.

The struggle for recognition as an equal in the management of international affairs is now a more credible proposition, as evidenced in Russia's remarkably effective intervention in Syria from September 2015 (even though the end game of the Syrian civil war may entail intensified great power conflict). At the tenth BRICS summit, held in South Africa in July 2018, Putin noted that the group had developed into "a full-scale organisation with new spheres of activity and broader common interests." The main topics discussed were "resistance to unilateral approaches in global affairs, the protection of multilateralism," and the condemnation of 
economic sanctions and the use of force in violation of the UN Charter (Kremlin.ru 2018). BRICS established its New Development Bank in July 2014, based in Shanghai but with plans to open regional branches in all the BRICS members. At that time the BRICS accounted for 26.5 of the world's land area, 42.6 per cent of world population, and according to the IMF in 2015 generated almost a quarter of the world's GDP and contributed more than half of global economic growth in the previous decade (RT 2018). George Toloraya (2018), executive director of the Russian National Committee on BRICS research, argued that "BRICS is about world order," creating its own structure of global governance "to create a world order that will be more just and balanced than what we see now."

Russia and China are not the harbingers of a new nationalism but of a new internationalism. Both insist on the equal status of all countries under international law. Under the flag of this principle they contested the slide towards democratic majoritarian rule in international politics, and thus opposed humanitarian intervention unless sanctioned by the UN Security Council. They opposed attempts by the West to impose rules through majority decisions or the use of multilateral institutions for political purposes. This was the case when in July 2018 the majority of members of the Organisation for the Prevention of Chemical Weapons (OPCW) voted on the right to draw on outside expertise to assign responsibility for the use of chemical weapons, which Russia argued gave it a political role that it feared could be used by the West to pursue broader unrelated political goals. Moscow's concern at the perceived politicisation of the organisation opened up the possibility that Russia could even leave the Chemical Weapons Convention.

Overall, if the $20^{\text {th }}$ century was the century of ideology, then the $21^{\text {st }}$ in its Trumpian version is beginning to look rather more like the $19^{\text {th }}$, i.e. nationalistic and mercantilist. For the commentators who in 2014 condemned Russia's actions in Ukraine as a throwback to $19^{\text {th }}$ century, this would confirm a natural convergence between Putinite Russia and Trumpian America. However, this would be wrong for the reasons outlined above. Paradoxically, it is now Russia and China who are defending multilateralism and the governance institutions of international society. Both defend the traditional view of state sovereignty, but as noted this does not represent a simple reversion to Westphalian internationalism. Their conservative institutionalism is ranged as much against the Trumpian sovereignty discourse as it is against the expansive interventionism of the democratic institutionalists.

One of the more striking manifestations of the shift from stasis to change is that the very concept of "the West" is being challenged. It is not that Russia is looking to the East to build alliances with other illiberal states, the way that recent developments are categorised by defenders of the old liberal hegemony, but an expression of the changing realities of global politics. The West is no longer the centre of the world in economic and even normative terms. Values of good governance, defensible property rights, rule of law, free and fair elections remain embedded as the core values of international society, although tempered by developmental and security considerations in countries like Russia and China. In fact, if decoupled from the Western power system and its inexorably hegemonic demands, there is a greater chance for them to be achieved. NATO enlargement effectively militarised the democracy promotion efforts of the West, while unmediated EU enlargement and power projection into the contested "common neighbourhood" reinforced the view of critics in Moscow that "democratic institutionalism" represented a fundamental threat to Russia's security and national interests (Hahn 2018).

Not surprisingly, some Russian analysts take great glee in describing the travails of the disintegrating West. In their view, Trump's policy called into question the common interests and common values of some of the fundamental institutions of the old order. The G7 summit in Taormina, Italy, in May 2017 was considered a failure, while the one in La Malbaie, Canada, in 
June 2018 proved a veritable disaster. Trump's application of the transactional business model to his allies raised the question of whether the West would survive in its traditional form at all. This would provide an opportunity for the anti-hegemonic alignment to assume a greater share of the burden of global leadership, but only if the end of stasis in international affairs was accompanied by the positive transcendence of immobilism. However, just as after the end of the First Cold War, a negative transcendence is possible, intensifying the conflicts and deepening the Second Cold War. The inertia associated with the post-war stasis has deep roots, but its unravelling can have both positive and negative outcomes.

\section{Conclusion}

Is an alternative possible? Some years ago Andrew Hurrell $(2006,1)$ noted that the four BRIC countries had a certain "capacity to contribute to the production of international order, regionally or globally." At that time Russia was considered the outlier, since "the reality of the past two decades here has been one of decline and the dissolution of power" (Hurrell 2006, 2; MacFarlane 2006). Hurrell $(2006,2)$ noted that while a central theme of the $20^{\text {th }}$ century was the struggle of revisionist states to achieve equal rights, "the recognition of regional spheres of influence, and the drive for equality of status within formal and informal international institutions," and although in the recent period "the currency of power" may have changed, the issue of recognition "has been sharpened by the growth of the idea that international society should aim to promote shared values and purposes rather than simply underpin coexistence and help to keep conflict to a minimum." In the second decade of the $21^{\text {st }}$ century, Russia reemerged as an active player in international affairs, and although still only barely in the top dozen countries economically, its impressive military reform and re-equipment since the 2008 Russo-Georgian war allowed it to "punch above its weight". Stasis and change now balance each other, and although the post-First Cold War order is unravelling, this has given rise to both a Second Cold War and the emergence of an anti-hegemonic alignment. The question today is whether the latter can help transcend the former.

Although the sinews of a post-Western world are emerging, notably in the form of SCO and BRICS, it remains to be seen whether these bodies and countries behind them will be able to sustain the multilateralism of the last seven decades in the absence of the hegemon that had provided the security and support for such multilateralism to thrive. The post-Western world may well assume the characteristics of the pre-Western international system, dominated by vast competing empires. Nevertheless, Trumpian realism entails partial de-globalisation, and it would be the supreme irony if liberal internationalism and open markets were to be saved by the leaders of the anti-hegemonic alignment. This could herald a new age of posthegemonic internationalism, but it could equally inaugurate a new era of zero-sum conflict, protectionism, a drive to the bottom in regulatory standards and another three-decade-long Cold War.

\section{References}

Acharya, Amitav. 2017. "After Liberal Hegemony: The Advent of a Multiplex World Order." Ethics and International Affairs. https://www.ethicsandinternationalaffairs.org/2017/multiplex-world-order.

Averre, Derek and Lance Davies. 2015. "Russia, Humanitarian Intervention and the Responsibility to Protect: The Case of Syria." International Affairs 91, no. 4: 813-34. https://doi.org/10.1111/1468-2346.12343.

Carothers, Thomas and Frances Z. Brown. 2018. "Can U.S. Democracy Policy Survive Trump?" Carnegie Endowment for International Peace, October 1. 
https://carnegieendowment.org/2018/10/01/can-u.s.-democracy-policy-survive-trump-pub$\underline{77381}$.

Dunne, Tim and Christian Reut-Smith, eds. 2017. The Globalization of International Society. Oxford: Oxford University Press.

Flockhart, Trine. 2016. "The Coming Multi-Order World." Contemporary Security Policy 37, no. 1: 3-30. https://doi.org/10.1080/13523260.2016.1150053.

Forsberg, Tuomas and Hiski Haukkala. 2016. The European Union and Russia. London: Palgrave.

Hahn, Gordon. 2018. "Trump-Putin Summit." Russian and Eurasian Politics, July 5. https://gordonhahn.com/2018/07/05/trump-putin-summit.

Hurrell, Andrew. 2006. "Hegemony, Liberalism and Global Order: What Space for Would-be Great Powers?" International Affairs 82, no. 1: 1-19. https://doi.org/10.1111/j.14682346.2006.00512.x.

Ikenberry, G. John, ed. 2011. International Relations Theory and the Consequences of Unipolarity. Cambridge: Cambridge University Press.

Kissinger, Henry. 2014. World Order: Reflections on the Character of Nations and the Course of History. London: Allen Lane.

Kremlin.ru. 2018. "News Conference Following the BRICS Summit." July 27. http://en.kremlin.ru/events/president/transcripts/58119.

Larson, Deborah Welch and Alexei Shevchenko. 2003. "Shortcut to Greatness: The New Thinking and the Revolution in Soviet Foreign Policy." International Organization 57, no. 1: 77-109. https://doi.org/10.1017/S0020818303571028.

Maas, Anne-Sophie. 2016. EU-Russia Relations, 1999-2015: From Courtship to Confrontation. London: Routledge.

MacFarlane, S. Neil. 2006. “The 'R in BRICs: Is Russia an Emerging Power?” International Affairs 82, no. 1: 41-57. https://doi.org/10.1111/j.1468-2346.2006.00514.x.

Mearsheimer, John J. 2014a. The Tragedy of Great Power Politics. New York: W. W. Norton.

Mearsheimer, John J. 2014b. "Why the Ukraine Crisis is the West's Fault: The Liberal Delusions that Provoked Putin." Foreign Affairs 93, no. 5: 77-89. https://doi.org/10.1080/21598282.2017.1316436.

Mearsheimer, John J. 2018. The Great Delusion: Liberal Dreams and International Realities. London and New Haven: Yale University Press.

Milward, Alan. 2000. The European Rescue of the Nation State. $2^{\text {nd }}$ edn. London \& New York: Routledge.

Panarin, Alexander. 1998. Revansh istorii: Rossiiskaya strategicheskaya initsiava v XXI veke. Moscow: Logos.

Pouliot, Vincent. 2010. International Security in Practice: The Politics of NATO-Russia Diplomacy. Cambridge: Cambridge University Press.

RT. 2018. "BRICS Trade Surges by $30 \%$ as Global Market Influence of Developing Economies Grows - Putin." July 26. https://www.rt.com/business/434330-russia-brics-tradeeconomy. 
Sakwa, Richard. 2008. “'New Cold War' or Twenty Years' Crisis? Russia and International Politics." International Affairs 84, no. 2: 241-67. https://doi.org/10.1111/j.14682346.2008.00702.x.

Sakwa, Richard. 2017. Russia against the Rest: The Post-Cold War Crisis of World Order. Cambridge: Cambridge University Press.

Savranskaya, Svetlana, Thomas Blanton and Vladislav Zubok, eds. 2010. Masterpieces of History: The Peaceful End of the Cold War in Europe, 1989. Budapest \& New York: Central European University Press.

Savranskaya, Svetlana and Tom Blanton. 2017. "NATO Expansion: What Gorbachev Heard." National Security Archive of George Washington University, December 12. https://nsarchive.gwu.edu/briefing-book/russia-programs/2017-12-12/nato-expansion-whatgorbachev-heard-western-leaders-early.

Smith, Martin A. 2013. "Russia and Multipolarity since the End of the Cold War." East European Politics 29, no. 1: 36-51. https://doi.org/10.1080/21599165.2013.764481.

Sokov, Nikolai. 2018. "The Putin-Trump Summit: In Helsinki, Three Worldviews Will Clash." The National Interest, July 15. https://nationalinterest.org/feature/putin-trumpsummit-helsinki-three-worldviews-will-clash-25766.

Stuenkel, Oliver. 2016. Post-Western World: How Emerging Powers are Remaking Global Order. Cambridge: Polity.

Suzuki, Shoigu. 2008. "Seeking 'Legitimate' Great Power Status in Post-Cold War International Society: China's and Japan's Participation in UNPKO.” International Relations 22, no. 1: 45-63. https://doi.org/10.1177\%2F0047117807087242.

Taylor, Matthew, Nick Hopkins and Jemima Kiss. 2013. "NSA Surveillance May Result in Internet Break-up, Warn Experts." The Guardian, November 2. https://www.theguardian.com/world/2013/nov/01/nsa-surveillance-cause-internet-breakupedward-snowden.

Toloraya, George. 2018. "BRICS and the World Order." Valdai Club, July 25. http:/valdaiclub.com/a/highlights/brics-and-the-world-order.

Wendt, Alexander. 1992. "Anarchy is What States Make of It: The Social Construction of Power Politics." International Organization 46, no. 2: 391-425. https://doi.org/10.1017/S0020818300027764.

Wohlforth, William C. and Vladislav Zubok. 2017. "An Abiding Antagonism: Realism, Idealism, and the Mirage of Western-Russian Partnership after the Cold War." International Politics 54, no. 4: 405-19. https://doi.org/10.1057/s41311-017-0046-8.

Richard Sakwa joined the University of Kent in 1987 and was promoted to professorship in 1996. While completing his doctorate on Moscow politics during the Civil War (1918-21) he spent a year on a British Council scholarship at Moscow State University (1979-80), and then worked for two years in Moscow in the 'Mir' Science and Technology Publishing House. Before moving to Kent, he lectured at the University of Essex and the University of California, Santa Cruz. He is an Associate Fellow of the Russia and Eurasia Programme at the Royal Institute of International Affairs, Chatham House, Honorary Senior Research Fellow at the Centre for Russian, European and Eurasian Studies (CREES) at the University of 
Birmingham and since September 2002 a member of Academy of Learned Societies for the Social Sciences. 